may be too low $[9,10]$, assaying the ex vivo reactivity of bronchoalveolar lavage T-cells towards Mycobacterium tuberculosis-specific antigens by flow cytometry may further improve the diagnostic accuracy of on-site immune based assays for the diagnosis of smear-negative tuberculosis.

\section{Jafari* ${ }^{*}$ M. Ernst ${ }^{\#}$ and C. Lange*}

Divisions of ${ }^{*}$ Clinical Infectious Diseases and "Immune CellAnalytics, Research Centre Borstel, Borstel, Germany.

\section{STATEMENT OF INTEREST}

A statement of interest for C. Lange can be found at www.erj.ersjournals.com/misc/statements.shtml

\section{REFERENCES}

1 Jafari C, Ernst M, Strassburg A, et al. Local immunodiagnosis of pulmonary tuberculosis by enzyme-linked immunospot. Eur Respir J 2008; 31: 261-265.

2 Jafari C, Ernst M, Kalsdorf B, et al. Rapid diagnosis of smear-negative tuberculosis by bronchoalveolar lavage enzyme-linked immunospot. Am J Respir Crit Care Med 2006; 174: 1048-1054.

3 Barry SM, Lipman MC, Bannister B, Johnson MA, Janossy G. Purified protein derivative-activated type 1 cytokine-producing CD4+ T lymphocytes in the lung: a characteristic feature of active pulmonary and nonpulmonary tuberculosis. J Infect Dis 2003; 187: 243-250.
4 Sester M, Sester U, Clauer $\mathrm{P}$, et al. Tuberculin skin testing underestimates a high prevalence of latent tuberculosis infection in hemodialysis patients. Kidney Int 2004; 65: 1826-1834.

5 Walrath J, Zukowski L, Krywiak A, Silver RF. Resident Th1-like effector memory cells in pulmonary recall responses to Mycobacterium tuberculosis. Am J Respir Cell Mol Biol 2005; 33: 48-55.

6 Breen RA, Hardy GA, Perrin FM, et al. Rapid diagnosis of smear-negative tuberculosis using immunology and microbiology with induced sputum in HIV-infected and uninfected individuals. PLoS ONE 2007; 2: e1335.

7 Breen RA, Barry SM, Smith CJ, et al. Clinical application of a rapid lung-orientated immunoassay in individuals with possible tuberculosis. Thorax 2008; 63: 67-71.

8 Jafari C, Bossink A, Goletti D, et al. Comparison of bronchoalveolar-lavage enzyme-linked immunospot and PCR for the diagnosis of smear negative tuberculosis: interim analysis of a TBNET study. Pneumologie 2008; 62: S130.

9 Lange C, Ernst M, Strassburg A, Sarrazin H, Jafari C. Diagnosis of smear-negative tuberculosis in low prevalence countries: keeping the scope on the bronchoscope. www. plosone.org/annotation/listThread.action?inReplyTo=info: doi/10.1371/annotation/57f8f244-15cc-4bd2-8847-33b2c319 ed3e\&root =info:doi/10.1371/annotation /57f8f244-15cc4bd2-8847-33b2c319ed3e Date last updated: May 8, 2008

10 Brightling CE. Clinical applications of induced sputum. Chest 2006; 129: 1344-1348.

DOI: 10.1183/09031936.00059308

\title{
A green humidifier chamber
}

\section{To the Editors:}

A patient presented with a continuous positive airway pressure (CPAP) humidifier chamber that was coated in a green residue (fig. 1). This has never been seen before in our clinic, which has managed $>6,500$ patients on CPAP. He had been washing the chamber in soapy water, then rinsing it in tap water. Analysis of the patient's water supply found $0.7 \mathrm{mg} \cdot \mathrm{L}^{-1}$ of copper, which is considered to be below acceptable limits set by the 2004 Australian Drinking Water Guidelines for health and aesthetic considerations. Chemical testing of the residue using scanning electron microscopy with energy dispersive X-ray analysis and Fourier transform infrared spectroscopic analysis found that it was predominantly calcium stearate, with trace amounts of copper, calcium, aluminium, silicon and oxygen. Calcium stearate is an insoluble calcium salt of stearic and palmitic acids. It is formed when soap is mixed with "hard" water containing calcium ions. Over time, a build up of calcium stearate had caused the green residue within the chamber.

\section{J. Tolson, P. Rochford and C. Worsnop}

Austin Health, Heidelberg, VIC, Australia.

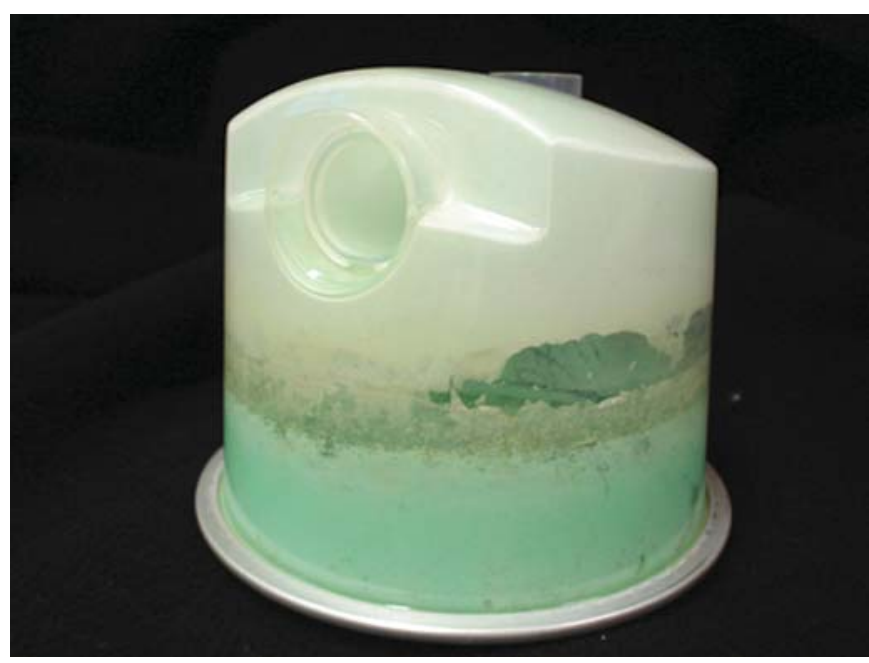

FIGURE 1. A continuous positive airway pressure humidifier chamber coated with a green residue due to a build up of calcium stearate. 